\title{
UJI KINERJA ALAT PENGOLAH KAHWA DAUN (TEH HERBAL SUMATERA BARAT)
}

\author{
Andi Eviza ${ }^{1}$, Rilma Novita ${ }^{2}$, dan Irzal $^{2}$ \\ ${ }^{1}$ Jurusan Budidaya Tanaman Perkebunan Politeknik Pertanian Negeri Payakumbuh \\ ${ }^{2}$ Jurusan Teknologi Pertanian Politeknik Pertanian Negeri Payakumbuh \\ Email: evie.tadjuddin@gmail.com; rilma.novita@yahoo.com
}

\begin{abstract}
ABSTRAK
Kahwa daun adalah teh herbal produk kearifan lokal Sumatera Barat. Kahwa Daun dibuat dari daun kopi segar dan membutuhkan waktu sekitar 2 minggu jika diolah dengan cara pengolahan tradisional. Produk yang dihasilkan dengan cara tradisional masih terbatas dan hanya dapat memenuhi kebutuhan skala rumah tangga. Seiring dengan diperkenalkannya kembali teh herbal ini awal tahun 2000, maka kahwa daun berkembang menjadi salah satu minuman alternatif yang diminati oleh masyarakat. Hal ini mengakibatkan naiknya kebutuhan terhadap produk kahwa daun dan mutu produk yang dihasilkan. Tantangan ini tidak dapat dijawab oleh produksi secara tradisional. Berdasarkan latar belakang ini maka dirancang alat pengolahan kahwa daun dengan tujuan dapat meningkatkan kapasitas produksi kahwa daun dan mutu produk yang dihasilkan. Pada tahap awal dilakukan uji kinerja alat. Peralatan dirancang dan dibuat terdiri dari silinder berputar yang digerakkan oleh motor listrik 0,25 HP, terbuat dari stainless steel, dan energi panas untuk pengeringan bersumber dari kompor LPG. Hasil uji coba kinerja alat dengan 4 perlakuan $(6 ; 8.5$; 10.5; dan $12 \mathrm{rpm}$ ), dengan variasi waktu penyangraian diketahui kadar air menyerupai kadar air produk tradisional tercapai setelah $120-135$ menit, pada $8.5 \mathrm{rpm}$ dan $10.5 \mathrm{rpm}$ atau setelah $105-120$ menit, pada $12 \mathrm{rpm}$. Jumlah produk akhir tertinggi dihasilkan dari alat yang diputar dengan kecepatan $10.5 \mathrm{rpm}$ dengan berat $3,8 \mathrm{~kg}$ kahwa daun dari $10 \mathrm{~kg}$ daun segar. Diketahui alat memiliki kapasitas produksi lebih tinggi dan waktu produksi lebih singkat dibandingkan cara tradisional pada $10.5 \mathrm{rpm}$. Kata kunci-kahwa daun; uji kinerja; rancang bangun; kapasitas produksi
\end{abstract}

\section{PENDAHULUAN}

Kahwa daun adalah produk asli Sumatera Barat yang terbuat dari daun kopi yang dikeringkan dengan cara tradisional sehingga dihasilkan produk berupa teh yang dikategorikan teh herbal. Air seduhan kahwa daun disebut aia kawa (minuman kahwa daun). Kahwa daun diproduksi oleh produsen kahwa di Sumatera Barat dengan 3 cara yaitu pendiangan, pengasapan, dan pembakaran (Novita, Kasim, Anggraini, \& Prima, 2018).

Cara tradisional ini memiliki kelemahan diantaranya jumlah produk yang dihasilkan sedikit, tidak seragam, waktu pengolahan yang tidak dapat diukur bahkan cenderung lama, dan proses pengolahan harus diamati terus menerus agar produk yang dihasilkan tidak terbakar. Hal ini mengakibatkan pengolahan kahwa daun menjadi terbatas dan tidak terstandar. Dalam hal mutu dan keamanan produk, maka produk yang diproses secara tradisional belum dapat dijamin meski sebagai produk kearifan lokal tidak ditemukan laporan efek negatif dari mengkonsumsi minuman kahwa daun. Bahkan masyarakat meyakini bahwa minuman kahwa daun berpengaruh postif bagi kesehatan. Hal ini masih perlu diteliti. Produk yang melewati proses pengasapan diketahui memiliki kandungan polisiklik aromatic hidrokarbon yaitu senyawa yang dapat memicu kanker (Farhadian, Jinap, Abas, \& Sakar, 2010; Onwukeme \& Okafor, 2015) .

Kahwa daun mulai dikembangkan kembali pada tahun 2000-an tepatnya tahun 2001 di Tabek Patah Propinsi Sumatera Barat. Kahwa daun berkembang menjadi salah satu minuman alternatif yang diminati oleh masyarakat. Hal ini mengakibatkan naiknya kebutuhan terhadap teh herbal ini sekaligus tuntutan terhadap mutu dan keseragaman produk. Tantangan ini tidak dapat dijawab oleh produksi secara tradisional. Berdasarkan latar belakang ini maka dirancang alat pengolahan kahwa daun yang dapat meningkatkan kapasitas produksi kahwa daun dan keseragaman mutu produk yang dihasilkan.

Tujuan penelitian adalah untuk mengetahui kinerja alat pengolahan kahwa daun dengan berbagai perlakuan kecepatan putar silinder (RPM) terhadap kadar air dan rendemen produk. Pada tahap awal adalah uji kinerja alat untuk menghasilkan teh herbal kahwa daun. Rancang bangun alat 
berupa tabung/silinder berputar yang terbuat dari stainless steel dan digerakkan oleh motor listrik 0,25 HP, dan energi panas untuk pengeringan bersumber dari kompor LPG.

\section{METODOLOGI PENELITIAN}

\section{A. Waktu dan Tempat Penelitian}

Penelitian telah dilakukan pada bulan Maret - September 2018, di workshop Bengkel dan laboratorium Kimia Politeknik Pertanian Negeri Payakumbuh.

\section{B. Bahan dan Alat}

Bahan yang dibutuhkan untuk pembuatan alat penyangrai adalah: plat stainless steel tebal 2 $\mathrm{mm}$, pipa stainless steel 1,5 inchi, speed reducer, motor listrik 0,25 HP, kompor gas LPG 1 tungku sebanyak 3 buah, tabung gas LPG $5 \mathrm{~kg}$, besi siku, bearing, puli, batu gerinda, gas oksigen, gas argon, elektroda RB 3,2 mm, elektroda RB 2,6 mm, cat poxy, cat duco, tinner, kertas amplas, dan engsel. Alat yang digunakan untuk pembuatan alat penyangrai adalah : paket peralatan pengerjaan logam (las listrik, las karbit/asetylen, mesin bor, mesin bubut, mesin gergaji listrik, compressor, mesin gerinda tangan, mesin bor kawat, siku mal las, siku ukur, jangka sorong, rol besi, pahat besi, palu besar, palu terak las, tang kombinasi, tang pegang, ragum, meteran, rol sudut stel, kunci-kunci, gergaji besi tangan, alat cat semprot, obeng, perlengkapan pengamanan kerja, dan kipas angin listrik.

\section{Prosedur Penelitian}

Rancangan Struktural

1. Rangka yang terbuat dari besi siku

2. Tabung/silinder dan sirip pengaduk bahan yang terbuat dari plat stainless steel

3. Poros terbuat dari pipa stainless steel

4. Sistem transmisi untuk menyalurkan tenaga putar dari motor penggerak ke tabung silinder terdiri atas sepasang puli dan sabuk serta sebuah speed reducer

5. Sumber tenaga penggerak berasal dari motor listrik $0,25 \mathrm{HP}$

6. Sumber panas berasal api kompor gas elpiji dengan tiga tungku

\section{Rancangan Fungsional}

1. Rangka harus kuat untuk mendukung gaya yang bekerja pada saat alat tersebut sedang dioperasikan

2. Tabung/silinder yang berfungsi sebagai tempat bahan berlangsungnya proses pengolahan bahan

3. Tabung/silinder yang mempunyai sirip-sirip di bagian dalamnya dengan fungsi untuk membalikkan bahan saat dilakukan pengolahan

4. Tabung/silinder mempunyai pintu/corong untuk memasukkan bahan (inlet) dan pintu/corong yang dapat digeser untuk mengeluarkan bahan (outlet)

5. Corong pengeluaran berguna untuk mengarahkan bahan yang telah disangrai ke wadah penampung

6. Poros sebagai tempat berputarnya tabung/silinder saat beroperasi dan tempat mengalirkan asap ke dalam tabung/silinder.

7. Mempunyai sistem transmisi untuk menyalurkan tenaga putar motor penggerak ke poros alat pengolahan

8. Api dari kompor LPG sebagai sumber panas untuk pengolahan

\section{Uji Kinerja Alat Pengolahan Kahwa Daun}

Uji kinerja alat yang dilakukan adalah uji kinerja awal dengan mengukur kadar air, waktu proses, kecepatan silinder, dan jumlah produk akhir yang dihasilkan. Bahan baku berupa daun kopi segar dari jenis kopi robusta sebanyak $10 \mathrm{~kg}$ dipersiapkan dan diolah dengan kecepatan putaran tabung silinder $6 ; 8.5 ; 10.5$; dan $12 \mathrm{rpm}$. Variasi kecepatan putaran ini dilakukan untuk mendapatkan putaran tabung yang paling efektif dalam menghasilkan kahwa daun. Pemilihan kecepatan ini juga didasarkan pengamatan langsung di lapangan pada produsen yang mengolah kahwa daun secara tradisional. Tabung dilengkapi dengan 2 corong yaitu corong pemasukan bahan baku dan corong 
pengeluaran produk yang ditutup dengan plat yang diberi lubang untuk mengatur keluarnya uap air yang berasal dari penguapan air dari daun saat pengolahan. Proses lengkap disajikan pada Gambar 1.

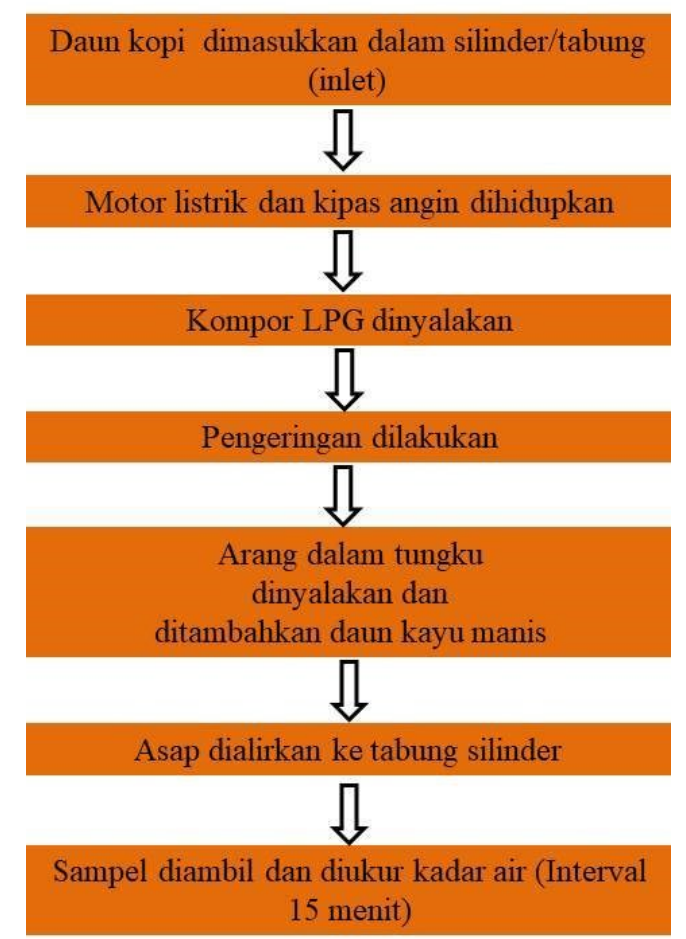

Gambar 1. Flowchart Pemakaian Alat

\section{HASIL DAN PEMBAHASAN}

Tujuan pengolahan makanan diantaranya adalah untuk memperpanjang umur simpan makanan sehingga makanan tetap aman, menyediakan variasi dan kenyamanan dalam diet, menyediakan/melengkapi kebutuhan nutrisi yang diperlukan untuk kesehatan, dan untuk memberikan nilai tambah pada produk (Fellows, 2000). Alat pengolahan kahwa daun berusaha mewujudkan hal ini. Hasil uji kinerja alat dilihat dari waktu pengeringan beserta kadar air produk yang dihasilkan dan rendemen produk. Peralatan pengolahan kahwa daun hasil rancangan dalam penelitian ini disajikan pada Gambar 2. Hasil uji coba kinerja alat dengan 4 tingkatan kecepatan putar silinder $(6 ; 8.5 ; 10.5$; dan $12 \mathrm{rpm}$ ) dapat dilihat pada Gambar 3.

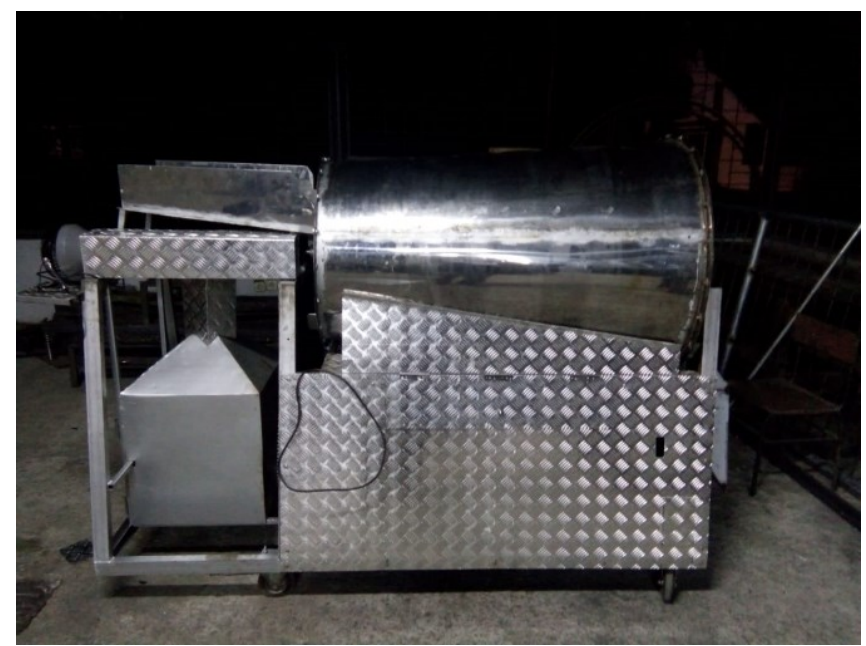

Gambar 2. Alat Pengolah Kahwa Daun 


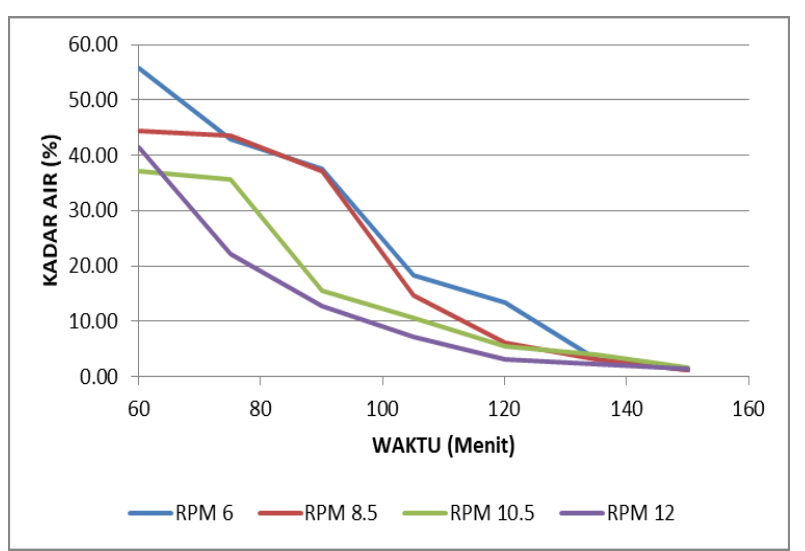

Gambar 3. Grafik waktu pengolahan terhadap kadar air kahwa daun

Proses pengolahan yang dilakukan terhadap daun kopi meliputi pengeringan dan pengasapan sehingga terjadi perubahan fisika dan kimia pada daun kopi. Pengeringan dilakukan dengan kontak langsung antara bahan dengan udara panas yang ada di dalam tabung/silinder dan dengan bantuan kipas yang terpasang di samping bagian pemasukan bahan. Uap air yang keluar dari bahan akan terbawa keluar melalui lubang-lubang yang terdapat pada corong pengeluaran. Prinsip pengeringan biasanya melibatkan dua kejadian, yaitu panas harus diberikan pada bahan yang akan dikeringkan, dan air harus dikeluarkan dari dalam bahan. Dua hal ini menyangkut perpindahan panas ke dalam dan perpindahan massa keluar. Menurut Singh and Heldman (2009), metode pengeringan bahan pangan dapat dilakukan dengan melewatkan udara kering (cabinet drier, tray drier, spray drier), kontak permukaan panas (drum drier), energi radiasi (microwave atau dielektrik) dan pengeringan beku (freeze dryer). Masing-masing metode pengeringan menghasilkan produk dengan karakteristik mutu tertentu.

Kadar air daun kopi segar yang diolah menjadi kahwa daun adalah $60,63 \%$. Kahwa daun yang diolah dengan kecepatan putar silinder $6 \mathrm{rpm}$ memperlihatkan penurunan kadar air yang paling lambat pada tahap awal pengeringan yang berlangsung selama 60 menit, yaitu sebesar 4,89\% (6 rpm), 16,18 $\%$ (8.5 rpm), 19,12\% (12 rpm) dan yang paling cepat adalah pada perlakuan dengan 10,5 rpm yaitu sebesar $23,42 \%$. Proses pengeringan yang terjadi untuk mengeluarkan air bebas dan air terikat secara fisika dari bahan berlangsung lambat, karena panas yang ada tidak cukup untuk menguapkan kandungan air tersebut dari bahan. Kandungan air suatu bahan terdiri dari air bebas, air yang terikat secara fisika dan air yang terikat secara kimia. Air bebas adalah air yang tidak terikat dengan bahan yang mempunyai sifat yang bebas, seperti air yang menempel di permukaan bahan (hasil pertanian), sehingga sangat mudah untuk diuapkan. Air yang terikat secara fisik adalah air yang terdapat di dalam ruang sel dan ruang antar sel bahan yang cukup mudah untuk diuapkan, sementara air yang terikat secara kimia adalah air yang terikat secara kimia didalam bahan yang sangat sulit diuapkan tanpa merubah kandungan kimia bahan. Pada proses pengeringan daun kopi terlihat bahwa penurunan kadar air berbanding lurus dengan besarnya kecepatan putar silinder sampai pada waktu pengeringan 120 menit. Proses pengeringan yang terjadi selama jam kedua disebabkan panas pada dinding tabung silinder sudah lebih tinggi sehingga proses pengeluaran kandungan air dari bahan dapat berlangsung lebih baik. Pada tahap pengeringan terakhir air yang tersisa di dalam daun kopi adalah air yang terikat secara kimia.

Selama proses pengolahan terjadi perpindahan panas dari tabung silinder (media penyangraian) ke bahan dan perpindahan massa air. Panas mengakibatkan terjadinya perubahan massa air dari bahan karena adanya panas laten penguapan. Perubahan massa air ini terjadi ketika kandungan air bahan telah sampai pada kondisi jenuh, sehingga menyebabkan air yang terkandung di dalam bahan berubah dari fase cair menjadi uap. Udara dalam proses pengeringan mempunyai fungsi sebagai pemberi panas pada bahan, sehingga menyebabkan terjadinya penguapan air. Fungsi lain dari udara adalah untuk membawa uap air hasil pengeringan bahan. Kecepatan pengeringan akan naik apabila kecepatan udara ditingkatkan. Kadar air saat mencapai kesetimbangannya, membuat waktu pengeringan ikut naik (lebih cepat).

Proses pengolahan daun kopi menjadi kahwa daun, proses pengeringan dilakukan untuk menghilangkan seluruh kandungan air bebas dan kandungan air fisika, kemudian dilanjutkan dengan 
proses pengasapan untuk membuang air kimia yang akan menyebabkan kahwa daun beraroma khas dan bisa diseduh menjadi minuman. Pada proses pengasapan, penurunan kadar air terbesar terjadi pada kecepatan silinder 10,5 rpm. Pengasapan membantu penguapan air kimia yang akan merubah kandungan kimia bahan yang ditandai dengan munculnya aroma khas kahwa daun. Pengasapan adalah proses pengawetan pangan yang paling lama dikenal manusia dan biasanya dilakukan terhadap daging dan ikan. Pengasapan memiliki tujuan utama untuk mendapatkan flavor dan warna produk disertai dengan terbentuknya beberapa senyawa yang memberikan efek sebagai pengawet. Pengasapan yang tidak terkontrol, dapat membahayakan kesehatan manusia. Karakteristik warna produk pengasapan dipengaruhi oleh nitrogen oksida. PAH dan senyawa fenolik berpengaruh pada citarasa produk pengasapan. Senyawa ini masih kontroversial dari sudut pandang kesehatan (S. M. Rahman \& Durance, 2002).

Kadar air produk tradisional berkisar antara 3.6-7.6 \% dengan waktu produksi 4 jam sampai 2 minggu dan rendemen produk 10-20\% (Novita et al., 2018). Kadar air yang sama dengan produk tradisional dapat dicapai dengan alat pengolahan kahwa daun dalam waktu 120-135 menit, jika menggunakan kecepatan putaran silinder $8.5 \mathrm{rpm}$ dan $10.5 \mathrm{rpm}$, dan dalam waktu 105-120 menit, jika menggunakan kecepatan putaran silinder $12 \mathrm{rpm}$. Jumlah produk yang dihasilkan dari $10 \mathrm{~kg}$ daun segar juga lebih banyak dari hasil produksi secara tradisional yaitu sekitar 30-38 \% (Tabel 1).

\section{Tabel 1. Kecepatan Putar Silinder dan Produk Akhir}

\begin{tabular}{lllll}
\hline Kecepatan $(\mathrm{rpm})$ & 6 & 8.5 & 10.5 & 12 \\
\hline Produk akhir $(\mathrm{kg})$ & 3 & 3.4 & 3.8 & 3.5 \\
\hline
\end{tabular}

\section{KESIMPULAN}

Berdasarkan hasil penelitian yang telah dilakukan, dapat disimpulkan:

1. Penurunan kadar air pada proses pengolahan kahwa daun dipengaruhi oleh kecepatan putaran tabung/silinder dan lamanya waktu proses pengolahan

2. Kahwa daun yang dibuat dengan alat pengolahan memiliki waktu pengolahan lebih cepat dan rendemen produk lebih tinggi

3. Pengolahan menggunakan alat direkomendasikan pada $10.5 \mathrm{rpm}$ selama 120-135 menit untuk kadar air menyerupai kadar air pengeringan tradisional dan produk akhir tertinggi.

\section{UCAPAN TERIMAKASIH}

Terima kasih penulis sampaikan kepada Kemenristekdikti yang telah membiayai penelitian ini melalui program PTUPT Tahun 2018 sehingga penelitian ini dapat berjalan lancar.

\section{DAFTAR PUSTAKA}

Farhadian, A., Jinap, S., Abas, F., \& Sakar, Z. I. 2010. Determination of polycyclic aromatic hydrocarbons in grilled meat. Food Control, 21(5), 606-610. https://doi.org/10.1016/j.foodcont.2009.09.002

Fellows, P. 2000. Food Processing Technology. Principles and Practice.

Novita, R., Kasim, A., Anggraini, T., \& Prima, D. P. 2018. Kahwa Daun; Traditional Knowledge Of A Coffee Leaf Herbal Tea From West Sumatera, Indonesia. Journal of Ethnic Foods, 5(4), 286291. https://doi.org/10.1016/j.jef.2018.11.005

Onwukeme, V. I., \& Okafor, R. N. 2015. Impact of Cooking Methods on the Levels of Polycyclic Aromatic Hydrocarbons (PAHs) in Chicken Meat. IOSR Journal of Environmental Science Ver. I, 9(4), 2319-2399. https://doi.org/10.9790/2402-09412127

Rahman, S. M., \& Durance, T. 2002. Handbook of Food Preservation. (M. S. Rahman, Ed.), Food Research International (second edi, Vol. 35). CRC Press. https://doi.org/10.1016/S09639969(00)00143-5

Singh, R. P., \& Heldman, D. R. 2009. Introduction to Food Engineering (Fourth Edi). Elsevier Inc. 